\title{
EL FLÂNEUR EN TOKIO. UNA LECTURA DE LA PANDILLA DE ASAKUSA DE YASUNARI KAWABATA
}

\author{
THE FLÂNEUR IN TOKIO. A READING OF THE SCARLET GANG OF ASAKUSA BY \\ YASUNARI KAWABATA
}

\author{
René Araya Alarcón* \\ Universidad Andrés Bello (UNAB), \\ Santiago - Chile. \\ Recibido febrero de 2019/Received February, 2019 \\ Aceptado julio de 2019/Accepted July, 2019
}

\begin{abstract}
RESUMEN
En primer término se analiza el concepto de flâneur. Para ello, se consideran las elaboraciones que desarrolló Walter Benjamin, a quien debemos el concepto, a propósito de la experiencia de Charles Baudelaire frente a las transformaciones urbanas y sociales que sufrió París a mediados del siglo XIX, durante el Segundo Imperio en Francia. Posteriormente se indaga en la configuración de la figura del flâneur en La pandilla de Asakusa de Yasunari Kawabata, a partir de la presunción de que se convocan en dicha novela los elementos temáticos y estructurales que justifican tal exploración.
\end{abstract}

Palabras Clave: Flâneur, C. Baudelaire, Y. Kawabata, La pandilla de Asakusa.

\begin{abstract}
To begin with, it will be analyzed the concept of flâneur, and for that, it will be taken into account the works of Walter Benjamin, to whom we owe the origin of this term. It will also be considered the experience of Charles Baudelaire facing the urban and social transformations that hit Paris in the 19th century during the Second French Empire. Subsequently, it will be explored the configuration of the figure of flâneur in The Scarlet Gang of Asakusa by Y. Kawabata. Based on the assumption that the thematic and structural elements associated to this concept flâneur, are present in this novel.
\end{abstract}

Key Words: Flâneur, C. Baudelaire, Y. Kawabata, The Scarlet Gang of Asakusa.

\section{KAWABATA Y LA PANDILLA DE} ASAKUSA

Yasunari Kawabata (1899-1972) publicó $L a$ pandilla de Asakusa en forma de folletín entre 1929 y 1930 en entregas semanales en el diario de mayor tirada de Tokio (Asahi Shimbun) ${ }^{1}$. Se trata de la segunda obra publicada por Kawabata, luego de la colección de cuentos reunida bajo el título de $L a$ bailarina de Izu, aparecida en 1926. A la luz de su producción posterior, que condensa como ninguna otra la esencia más atemporal de la civilización japonesa, La pandilla de Asakusa, escrita en un momento generacional marcado por la propuesta

* Autor correspondiente / Corresponding author: renearay@ gmail.com 
de renovación de la literatura japonesa a partir de la influencia de las vanguardias occidentales de las primeras décadas del siglo XX, adquirió siempre una extraña notoriedad en la producción de Kawabata. El propio novelista japonés llegó a repudiarla y a señalar que su lectura le causaba náuseas y vergüenza, a pesar de lo cual nunca se decidió a expurgarla de sus obras completas. La crítica, por su parte, también hizo notar la atipicidad estructural y temática del texto, actitud que pareció manifestarse incluso entre los editores, a través de tardías traducciones y publicaciones ${ }^{2}$, como si la ponderación del propio Kawabata hacia la novela hiciera sembrar dudas respecto de considerarla, o no, parte de su catálogo. Más allá de que el texto pueda considerarse, en efecto, producto de un período juvenil de ensayo o búsqueda, resulta evidente que esa misma consideración le otorga un estatus especial que debe ser atendido.

Precisamente, es su atipicidad en la producción narrativa de Kawabata la que vuelve interesante aproximarse a esas peculiaridades temáticas y estructurales y darle un lugar y sentido. Es para ello que proponemos aquí una aproximación desde el concepto de flâneur, resultando fundamental, desde esa perspectiva, analizar previamente y con algún énfasis, las conceptualizaciones desarrolladas por Walter Benjamin (quien introduce el concepto, cuestión que lo posiciona como referente insoslayable en la materia) a propósito de Charles Baudelaire, para luego analizar el modo en que dichos conceptos aparecerían configurados en La pandilla de Asakusa, presumiendo que tal subjetividad opera en la narración y contribuye a dar cuerpo a una lectura que le otorga sitio y contexto a las particularidades de lo producido por Kawabata entre 1929 y 1930.

\section{FLÂNEUR, IDENTIDAD COMO ESPECULACIÓN Y COMUNIDAD IMAGINADA}

El concepto de flâneur aparece vinculado al pensamiento de Walter Benjamin a propósito de lo moderno en la poesía de Baudelaire y el entorno urbanístico de París hacia mediados del siglo XIX (espacios y contextos que Baudelaire incorpora con insistencia en su producción, sobretodo en Pequeños poemas en prosa, que, en efecto, está imbuido del espíritu del flâneur desde lo temático y lo estructural), contexto en torno al cual Benjamin delimita y elabora el concepto, a fin de configurar un elemento que permita la comprensión de la producción de Baudelaire en el momento de la modernización de París durante el Segundo Imperio (Benjamin, 1991). La experiencia de Baudelaire es la experiencia del artista frente a lo moderno y su correspondiente interpretación estética: su obra, en efecto, diseñó la disciplina y el espíritu de la modernidad estética que alcanzó luego, con las Vanguardias Históricas, solo su culminación (Habermas, 2004). Sin embargo y como bien ha hecho notar Morales (2002), más allá de las circunstancias históricas implicadas en su origen y la aparente circunscripción al trabajo de Baudelaire, la pertinencia y productividad crítica del concepto de flâneur salta a la vista proyectándose más allá de esas delimitaciones, esto es, más allá de Baudelaire y del París de mediados del siglo XIX, ofreciéndose como un elemento que puede resultar clave al momento de analizar la emergencia de lo urbano moderno en el arte. De ahí que se proponga el análisis de La pandilla de Asakusa de Yasunari Kawabata en esa dirección. Sin embargo, por ahora, el examen y esclarecimiento del concepto se guiará orbitando en torno al trabajo de Baudelaire en el cual se asoma como explícito y claramente rastreable e identificable, para en un momento posterior analizar cómo se aplica el concepto a las dimensiones estructurales y temáticas de la novela de Kawabata.

Pues bien, la relación entre la figura del flâneur y ciertos espacios urbanos es estrecha y fundamental. La palabra flâneur alude a una figura del contexto cotidiano, en la medida en que se trata de un sujeto que pasea, pero que pasea por un espacio delimitado y específico que es la calle (Benjamin, 1991). Esto hace patente su pertenencia exclusiva a la vida urbana, pues solo en tales contextos adquiere pleno sentido y se configura propiamente (Morales, 2002; Muñoz Millanes, 1998). Tenemos, entonces, como primer elemento, que el flâneur es una figura eminentemente urbana. Pero además es una figura que pertenece a espacios urbanos claramente delimitables. Se vincula a los espacios urbanos modernos occidentales, y por lo tanto su aparición termina de definirse en la primera mitad del siglo XIX, pues entonces es que se producen las trasformaciones urbanísticas en el espacio europeo que permitirán las condiciones físicas espaciales para que el flâneur pueda deambular por la ciudad (Benjamin, 1991). 
En París, esas transformaciones se producen durante el Segundo Imperio en Francia, a mediados del siglo XIX, durante el gobierno de Napoleón III y bajo la planificación y dirección del político y urbanista George Eugène Haussmann (Morales, 2002; Harvey, 2006). Las necesidades que impusieron estas modificaciones fueron múltiples. Se requería de espacios que permitieran la implantación de modernas instalaciones urbanas que resolvieran, entre otras, problemáticas sanitarias, viales y de vivienda. Pero, sin lugar a dudas, una de las necesidades más relevantes se vinculaba a la posibilidad de garantizar ciertas ventajas militares estratégicas que permitieran contener eventuales movimientos revolucionarios (Calatrava, 2016). La transformación de París estuvo, en realidad, profundamente determinada por el temor a ala insurrección popular de $1848^{3}$ y a la resistencia que había encontrado el golpe de Estado de $1851^{4}$. Esa es la justificación última de la urbanización de la periferia de París, en particular de la apertura de bulevares anchos y rectilíneos articulados mediante plazas circulares: su propósito era impedir los ejercicios de defensa y barricada, facilitando el acceso de escuadrones militares a la periferia desde el centro de la ciudad. Lo anterior, supuso la demolición de extensas áreas del París medieval, en especial aquellas que habían destacado en la resistencia revolucionaria (Escobar, 2018). Lo que estuvo implicado en la modernización de París fue la puesta en práctica de un mecanismo o tecnología de control social por medio de la estructuración de dispositivos arquitectónicos y urbanísticos de orden disuasivo, donde resultaba fundamental que el transeúnte se volviera completamente "visible" (Harvey, 2006). El propósito era que eventuales movimientos revolucionarios, opositores al régimen de Napoleón III, no encontraran en la ciudad los espacios que facilitaran ejercicios de resistencia. El objetivo fue, por tanto, instalar en París una red panóptica dotada de espacios que garantizaran la visibilidad de los transeúntes y que contribuyera a regular disuasivamente la conducta, a través de la sensación de exposición y vigilancia, aprovechando la relación directa que existe entre tecnologías de poder y la densidad que adquiere una zona (Castro, 2009). Se trataba entonces, de generar, en el contexto del Segundo Imperio en Francia, espacios urbanos que, de acuerdo a las conceptualizaciones de Foucault, facilitaran el control de los cuerpos y la introducción de dispositivos disciplinarios, áreas en las que la inspección funcionase sin cesar y la mirada estuviera por doquier en movimiento (Foucault, 2006, 2007).

Pues bien, tal como examina y sugiere Benjamin (1991), son estas transformaciones las que generaron los espacios que condicionaron y permitieron la aparición del flâneur, en la medida en que ellos facilitaron su deambular y las condiciones que estos ejercicios requieren. El paseante o caminante encuentra a su paso espacios abiertos que le permiten desplazarse de una calle a otra, circular por distintos sectores urbanos y bulevares, y de ese modo abocarse a su principal ocupación: observar. Aquello que el flâneur observa, desde su particular sensibilidad, es la irrupción de una reconversión social asociada a la transformación arquitectónica: las modificaciones urbanas en París, sobretodo la apertura de bulevares anchos y largos e interconectados, permitió, al mismo tiempo el deambular del flâneur, la irrupción en el paisaje urbano del fenómeno de la multitud: un conjunto anónimo, disgregado, ajeno a la idea comunitaria de sociedad y que se apodera de estos espacios nuevos que permiten amplios desplazamientos y que inauguran nuevas modalidades de interacción:

Ya el hormigueo de las calles tiene algo de repugnante, algo en contra de lo cual se indigna la naturaleza humana (...). La indiferencia brutal, el aislamiento insensible de cada uno de sus intereses privados, resaltan aún más repelente, hiriente, cuanto que todos se aprietan en un pequeño espacio. (Engels, 1848, como se citó en Benjamin, 1991, p. 74).

Es precisamente, esa indiferencia brutal y aislamiento insensible que F. Engels detecta en las calles de Londres, el que otorga anonimato al flâneur para deambular por la ciudad y abocarse a sus ejercicios de rastreo y observación. La multitud le sirve como refugio para sus actividades voyeuristas. Como hemos dicho se trata de una multitud ajena a cualquier idea de sociedad como comunidad, desgarrada como unidad y que aparece como espectro, convertida en una sociedad moderna, es decir, adviene como artefacto o constructo. Esto es, multitud como grupo humano que comparte espacios, pero que no responde a raíces o motivaciones comunes, construida artificialmente como sociedad o grupo. Es decir, y de acuerdo a las elaboraciones de B. Anderson, se trata ya de una comunidad imaginada (Anderson, 1991). 
Charles Baudelaire es testigo privilegiado de las transformaciones urbanísticas que tienen lugar en París promediado el siglo XIX, y recogió este hecho en varios de sus textos, expresando el efecto negativo que esos cambios provocaron en él e intuyendo los que provocaban y causarían en la ciudad como espacio, y desde luego en sus habitantes (Campaña, 2017). En los "Ojos de los pobres" alude precisamente a uno de los bulevares del diseño Haussmann, nuevo o en construcción, lleno de escombros y que ya exhibe su esplendor inacabado (Baudelaire, 1997), y en "El cisne" de Las Flores del mal refiere al aura que pierde París irremediablemente bajo el influjo de sus transformaciones urbanas:

¡París cambia, mas nada en mi melancolía se ha movido! Andamiajes, palacios, horizontes,

viejos barrios, ya todo se me hace alegoría... ¡Son mis caros recuerdos más pesados que montes! (Baudelaire, 1997, pp. 139-140).

Baudelaire deambula por París y en sus textos configura el hablante poético que Benjamin conceptualiza a través de la figura del flâneur: Baudelaire es, en efecto, el flâneur de París, que asume, respecto de las transformaciones de las que está siendo testigo, una distancia crítica. Comparte el espacio de la multitud y valiéndose del anonimato del que goza al atravesar la ciudad, observa y examina desde una postura crítica. Es precisamente esa postura la que lo separa y distingue de la masa, imponiéndole una natural distancia entre él y la muchedumbre:

No albergo convicciones, tal como las entienden las gentes de mi época, porque carezco de ambición. En mí no existe base para una convicción (...). No obstante, tengo determinadas convicciones, en un sentido más elevado, que no pueden ser comprendidas por las gentes de mi época. (Baudelaire, 1961, p. 689).

Baudelaire se siente inmerso en una masa indiferente no solo a su producción literaria, sino también a su propia experiencia. En la vorágine de la gran ciudad las relaciones han perdido todo matiz afectivo. En este contexto la figura del flâneur debe afrontar la paradoja de estar estructurado entre la soledad y la multitud y su dependencia de ambas circunstancias: requiere del aislamiento como requisito en su condición de observador, pero al mismo tiempo requiere de los espacios donde se desenvuelve la multitud para ejercer tal condición. Esto lo sitúa en una paradoja: desprecia a las multitudes - "hay personas que no pueden divertirse más que en tropel, el verdadero héroe se divierte absolutamente solo" (Baudelaire, 1997, p. 113) - pero son su objeto de observación. El flâneur huye de la mirada del otro, pero necesita imponer su mirada sobre la multitud y perderse para ello en la masa anónima. Con la superioridad psicológica que siente el que observa sin ser visto, el poeta dirige su mirada sobre la multitud que hormiguea por los laberintos de la metrópoli, buscando e indagando señales, signos que le permitan configuran sentidos en medio de la multitud desgarrada y articular rastros de la comunidad desvanecida. El deambulador parisiense, el paseante solitario, adopta así una actitud de observación, pues "en determinados estados del alma casi sobrenaturales, la profundidad de la vida se revela por entero en el espectáculo, por irrelevante que sea, que uno tiene ante sî" (Raymond, 1961, p. 17). Desde luego que la mirada del flâneur no es una mirada pasiva, neutra, solo registradora, ni tampoco una mirada meramente curiosa, sino es una mirada que examina y que funciona de acuerdo a un principio activo de selección y construcción:

\begin{abstract}
El movimiento comienza cuando algún transeúnte azaroso entra en el foco de la mirada y ésta se detiene, inquisitiva, en determinados detalles de la vestimenta del rostro o de la gestualidad. A la mirada del flâneur, tales detalles se trasforman en signos. En un primer momento, signos con un significado más bien residual, difuso opaco, dispersos, incapaces ya de hacer transparente una identidad (la del otro). En un segundo momento, la imaginación del flâneur hace de ellos signos de una identidad ahora especulada, construida. (Morales, 2002, p. 34).
\end{abstract}

La tarea del flâneur consiste en extraer lo eterno de lo transitorio, de la escena fugaz del personaje que solo se cruzará una vez en su camino (López Castellón, 1997). La disolución de la comunidad y su transformación en artefacto, despoja a sí misma a la subjetividad de una identidad aprehensible y definida. En su deambular el flâneur encuentra a su paso solo signos 
dispersos y difusos. La tarea del flâneur reside precisamente en ello: debe rastrear fragmentos, rastros dispersos que configura y reconstruye como signos hasta dar una forma a una identidad especulada, es decir ya no aprehensible en tanto unidad más que como especulación. El objetivo es leer signos residuales a partir de las rutinas urbanas para construir con ellos identidades. Se sugiere así una posición posmoderna: sujetos e identidades construidos a partir de fragmentos. Precisamente la ida de recabar significados dispersos deriva del sentimiento de pérdida de unidad del sujeto tal éste como había sido concebido hasta el siglo XIX, acontecimiento que se encuentra vinculado a la desintegración de la sociedad como comunidad y convertida en artefacto. Es, debido a ese motivo, que las construcciones de signos de identidad no pueden adoptar la forma de una línea continua o ininterrumpida. Esta continuidad está impedida o restringida, y debido a eso, en la sociedad moderna construida como artefacto, el flâneur puede ocuparse solo de estímulos dispersos, erráticos e intermitentes. La identidad se vuelve así ensayo, intento (Morales, 2004). En este contexto, los vínculos comunitarios han sido sustituidos por la mera adición de individuos (Morales, 2002), y debido a eso lo único rastreable son elementos dispersos. Por eso la observación del flâneur ejecuta sobre una mirada interrumpida, que ciertamente es fragmentaria, de ahí que la obra solo pueda adquirir una estructura inorgánica, a partir de la cual cada una de las partes se retrotrae como unidad, pero no como unidad propiamente, sino como artefacto. En esta modalidad de construcción, Baudelaire está anticipándose a la estética fragmentaria de las vanguardias históricas (Morales, 2002) que propondrán precisamente una obra que expulsa de sí la continuidad y linealidad y que se construye desde un orden fragmentario (Bürger, 2010). Eso es precisamente lo que intenta el flâneur como observador privilegiado: la construcción de signos de identidad donde solo hay signos dispersos (Morales, 2002). Con estas exploraciones hemos dado cuenta de las principales condiciones y características de la figura del flâneur.

\section{EL FLÂNEUR EN TOKIO:} KAWABATA Y ASAKUSA

¿Es admisible considerar que se convocan (y de qué forma) en La pandilla de Asakusa los elementos que permitan delimitar la figura del flâneur? Las condiciones, como ha sido visto, son al menos las siguientes: debe tratarse de una figura del devenir cotidiano moderno tal como éste se desarrolla en las ciudades europeas a partir de mediados del siglo XIX cuando se instala la idea de multitud. Dicha subjetividad debe pasearse por espacios públicos con una conciencia y ocupaciones distintas a la de la multitud y revelar un esfuerzo o capacidad de construir, desde una lógica fragmentaria, signos de identidad en un momento en que lo que se asoma es la pérdida de la unidad del sujeto y de la sociedad como comunidad. La conjunción de estos elementos revela, en definitiva, la actitud estética moderna que inauguró Baudelaire.

Al comenzar, digamos que Kawabata sitúa su novela en un espacio particular de Tokio. Se trata del barrio de Asakusa, el que fue durante las últimas décadas del siglo XIX y la primera mitad del siglo XX, el mayor centro de entretenimientos de la capital japonesa. En sus orígenes, Asakusa no era parte de Edo (nombre original de la ciudad de Tokio). Establecido fuera de sus límites, solo cuando se prohibieron los teatros y burdeles en Edo hacia 1840, Asakusa y Yoshiwara (el barrio autorizado por el gobierno para ejercer la prostitución) fueron designados lugares de placer, "tolerados refugios de los rigores de la severidad samurai de otros lugares de la ciudad" (Richie, 2007). Asakusa se convirtió entonces en el lugar del espectáculo y del entretenimiento, con calles atestadas de teatros, cines, restaurantes, casas de geishas y de todo tipo de mercancías y atracciones. Cabe señalar, en este punto, que de a acuerdo a Benjamin, la figura del flâneur emerge a mediados del siglo XIX, y se vincula a espacios occidentales y modernos (Benjamin, 1991). En efecto, de acuerdo a Morales (2002), la figura del flâneur es del todo ajena a las vidas cotidianas urbanas no occidentales. Sin embargo, la pertinencia de considerar como posible la configuración del flâneur en un espacio oriental, como Tokio, está dada precisamente por el hecho de que el barrio de Asakusa se convirtió, precisamente bajo el influjo de nociones como las de espectáculo y mercancía, en un espacio donde las tradiciones japonesas cedieron a los influjos occidentales. Asakusa, situado al margen de los barrios tradicionales, se convirtió en una suerte de espacio occidental trasplantado a la periferia de Tokio. Es precisamente esta condición (de modernización entendida como occidentalización) la que, como se verá, facilita o posibilita la lectura 
de la novela de Kawabata desde el concepto de flâneur.

Debido a sus múltiples distracciones, Asakusa se convirtió en un espacio abierto a la multitud ávida de entretenerse con algunos de los espectáculos disponibles o de adquirir algunas de las mercancías que ahí se transaban. La muchedumbre que desborda Asakusa observa y asiste, como ha sido dicho, a una reconversión social: la occidentalización de las tradiciones japonesas paralelamente a la emergencia de la ciudad moderna. La multitud asiste, sin embargo, a esta transformación fascinada, ciega a las implicancias de dichas transformaciones, incapaz de reflexionar en torno al bosquejo del nuevo orden. Pero al mismo tiempo, sin embargo, comienzan a emerger ciertas subjetividades dotadas de sensibilidad especial que son capaces de intuir que algunas transformaciones están teniendo lugar, y cuya motivación particular es situarse en la multitud y observar su funcionamiento desde el interior. Obsérvese el discurso del personaje de uno de los relatos de J. Tanisaki:

Cambiando de ropa todas las noches para no ser identificado, me zambullía en la multitud de parque de Asakusa... una noche me até una bufanda sobre la cara, me puse una campera corta de algodón a rayas, me pinté de rojo las uñas de los pies cuidadosamente acicalados, y me calcé unas sandalias de suela de cuero. Otra noche salí con anteojos negros (...) Disfrutaba poniéndome una barba postiza, un lunar o una mancha de nacimiento para alterar mis rasgos. Pero una noche, en un negocio de ropa usada... vi un quimono de mujer que tenía un dibujo a cuadros sobre un fondo azul, y fui asaltado por el deseo de probármelo. (Tanisaki, 1993, pp. 161-162).

Tanisaki ha escrito su relato $E l$ secreto en 1911, durante el apogeo de Asakusa y en él se vuelven visibles o enunciables al menos dos elementos. El primero guarda relación con el hecho, ya señalado, de que la multitud de Asakusa posibilita la emergencia de subjetividades curiosamente impulsadas a extraviarse en la multitud y a pasar desapercibidos o no ser identificados mientras deambulan por ella, en busca de alguien o algo que no logran discernir, pero que, sabemos, se trata de señas de identidad en un momento de signos dispersos, autopsiados, travestidos. El segundo elemento intuido por Tanisaki, se vincula precisamente, al hecho de que en Asakusa (el lugar donde la tradición se occidentaliza), las identidades comienzan a desvanecerse, a volverse difusas, apenas un juego de apariencias, donde todo lo que hay son signos residuales, incompletos. Tanisaki lo metaforiza precisamente en el uso compulsivo de disfraces, pues se trata precisamente de disfrazar una cultura. Es el momento y el espacio en que se produce el choque entre las tradiciones milenarias de Japón con el florecimiento de la ciudad moderna, es decir, el momento en que la identidad y la sociedad como comunidad es puesta en entredicho precisamente por el collage en que se convierte Asakusa. La multitud que pasea por Asakusa no tiene ya un sentido de pertinencia y este impulso que densifica las calles atestadas de teatros, bares de jazz y burdeles y cines destartalados es ya un sentido de comunidad artificial, propiamente un artefacto, un trasplante. Los entretenimientos y objetos que ahí se exponen tienen ya las señas de la mercancía tal como las piensa Debord (1999): espectáculos que simplemente se distancian en la representación, y que solo pueden exhibir su vacío, pues los signos culturales comienzan a destriparse, autopsiarse. Los objetos, en tanto signos, comienzan a sufrir los efectos de lo que $\mathrm{F}$. Jameson denomina fuerza de reificación, es decir, a constituirse como significantes desimantados de sus significados (Jameson, 2012).

Kawabata creció precisamente mientras Japón se abría a la civilización occidental:

El fin del régimen feudal y la centralización de la autoridad en un emperador restaurado iniciaron procesos que ya no se detendrían, como parte de una modernización entendida como occidentalización. Se adoptaron usos desconocidos propios de una identidad moderna: pantalones, ropa interior, bailes de salón, feminismo, estudios extranjeros, cigarrillos, etc. "Lo nuevo" irrumpió con gran fuerza en ambientes provincianos caracterizados por un feroz autoritarismo. (Silva, 2007, p. 9).

Esta reconversión social que acontece, progresivamente, en todo Japón, encuentra una expresión radical y explícita en Asakusa. Kawabata es consciente de esta modernización entendida como occidentalización y manifiesta de modo explícito su desconcierto ante la "pérdida de alma" que significa para Japón una excesiva influencia de occidente. 
Todos esos "usos" y mercancías occidentales que se incorporan al devenir cotidiano japonés están desprovistos de sentido, de forma tal que asistir a Asakusa, el trastero de Tokio, es asistir al fin de la idea de una identidad común, o a su decadencia o perversión. Eso es precisamente lo que recrea Kawabata en la pandilla de Asakusa. La pérdida de la identidad, la desaparición de una tradición y por lo tanto la implantación de una comunidad imaginada, apenas un artefacto, derivada del encuentro de dos mundos marginales. Kawabata elige precisamente como eje de la narración a una pandilla que opera en el parque de Asakusa, y que

Ilustra un nuevo tipo de reacción ante el cruce obligado de dos mundos marginales, uno japonés tradicional y otro occidental moderno. Encarna la libertad de escoger elementos de aquí y de allá, sin fidelidad a la tradición vernácula o a la moda extranjera. Trata de reconstruir la propia identidad mediante un montaje microsocial de códigos estrictos, uniformes distintivos, fajas, colores, distribución de roles, lenguaje codificado. (Silva, 2007, p. 12).

Los miembros de la pandilla escarlata (llamados así precisamente por usar un distintivo de la tradición nipona, una etiqueta votiva escarlata) deambulan por Asakusa buscando signos, señas dispersas que poder adosar a su identidad. Asakusa impone por lo tanto un espacio de destradicionalización (la pandilla simplemente usa la etiqueta votiva, pero ese uso no conlleva otras prácticas, es un significante vacío, desprovisto de significado), es decir, un momento en el que de acuerdo a U. Beck, la tradición pierde su estatus y puede ser cuestionada (Beck, Giddens, \& Lash, 2001). Un momento de reflexividad, por lo tanto, en que la tradición se vuelve un problema para sí misma. Asakusa impone un momento de identidades de hágalo usted mismo, es decir un momento en que las subjetividades ajenas a toda comunidad deben ser artífices de su propia biografía e identidad (Beck, Giddens, \& Lash, 2001). Ya no existe una experiencia común o una identidad compartida que sitúe a los sujetos en un margen identitario. Lo que queda es simplemente el fragmento, la comunidad desmantelada y los rastros dispersos que los sujetos se adosan para constituir algo semejante a una identidad. La búsqueda de pandilla escarlata es, en realidad, la búsqueda de una identidad, a la que, desde luego, solo puede accederse por medio de fragmentos o signos residuales. Esa es precisamente la tarea de la pandilla escarlata, trajinar Asakusa en busca de vestigios o residuos con los cuales configurarse una identidad. Y es también la búsqueda del narrador de la novela que, en efecto, deambula por Asakusa y, como si se tratara de un video experimental o un documental construido de fragmentos, ofrece imágenes dispersas que debe "organizar".

Kawabata da cuenta de esta búsqueda o rastreo de signos dispersos con los que configurar un bosquejo de unidad, y expresa, entretanto su malestar frente al hecho de que Asakusa es "una fundición en la que los viejos modelos son fundidos para formar otros nuevos" (2007, p. 78), y también frente a las mezclas culturales que tienen lugar: "Si bien no soy de escandalizarme por cosas como el jazz kappore, pienso que con esa danza mixta (...) han ido demasiado lejos: están mezclando demasiado" (2007, p. 192). O bien:

Y (otro ejemplo) ese instrumento musical que
es una mezcla de piano y máquina de escribir
(todos los conocemos como el "Taisho koto",
pero ahora algunos comerciantes emprende-
dores lo llaman el "Showa koto"). Así son las
cosas en nuestros días. Simplemente ninguna
nostalgia por la antigua Edo". (Kawabata,
2007, p. 48).

En el momento de la disolución de la sociedad como comunidad sujeta a una tradición y a una sabiduría común, lo que queda es la imposición de las identidades como reunión de fragmentos. La multitud no es una comunidad articulada: es cierto, comparte un espacio, pero sus motivaciones son ya particulares y aparecen en un marco destradicionalizado. Kawabata es consciente de esto y su novela no solo da cuenta del estado de las cosas desde una perspectiva temática, sino también, como examinaremos ya, desde una perspectiva estructural.

Kawabata, tal como el Baudelaire en París, se convirtió en el flâneur de Tokio. Para cuando redacta La pandilla de Asakusa, ya había publicado con éxito La bailarina de Izu, un texto de naturaleza muy diferente. Sin embargo, es el momento de la emergencia de lo moderno y Kawabata, al igual que otros escritores japoneses (como Natsume Soseki o Junichiro Tanisaki), decide ir al lugar 
que facilitaría el emprendimiento de un proyecto literario que permitiera la exploración de nuevas formas narrativas. Kawabata desea experimentar con formas modernas y para ello busca el material adecuado en Asakusa. En efecto, se muda al barrio marginal de Tokio y durante tres años, convertido en voyeur, deambula por sus calles sin interrogar a la gente, simplemente tomando notas (Silva, 2007). Kawabata se convierte literalmente en un flâneur, y valiéndose de la condición de anonimato que la multitud facilita, simplemente observa y registra: "Todo lo que hice fue caminar. Nunca tomé contacto con algunos de los jóvenes delincuentes. Tampoco nunca dirigí la palabra a los vagabundos... pero tomé mis notas" (Kawabata, 1968, como se citó en Keene, 1984, p. 656). Luego al reunir su material, cuando redacta la novela, todo lo que tiene delante de sí es una suma de fragmentos. Ha sido durante tres años un espectador de un espacio fragmentario, desprovisto de identidad sino como mezcla o búsqueda. Es cierto que Kawabata estaba buscando experimentar con nuevas formas narrativas (que lo vincularon a la estética que perseguía la escuela de la Nueva Percepción), pero más cierto es que aquello que intentaba narrar no era posible de ser narrado sino desde la perspectiva de la fragmentariedad. Se trata, ciertamente, de la experiencia del artista en la ciudad moderna, que debe enfrentar cualquier configuración desde la lógica del montaje o collage de ideas dispersas que intentan reflejar unidad. Se trata, como supone Martínez Bonati, de un momento en que no caben narraciones como dispositivos de saber, sino descripciones o "lecturas" siempre inacabadas: escritura como ensayo (Martínez Bonati, 1995). Tal y como ha supuesto W. Benjamin, las sociedades han perdido toda capacidad para expresar sabiduría y solo cabe compartir experiencias fragmentarias y dispersas (Benjamin, 2018). Debe recordarse aquí que Kawabata fue un gran lector de las Vanguardias de Entreguerra y que está intentando escribir una novela moderna, ensayando nuevos estilos:

El intento de adoptar alguna de las técnicas del modernismo europeo y la lucha por desprenderse de las tendencias simplificadoras demasiado realistas y autobiográficas, que dominaron las dos primeras décadas del siglo XX en Japón, son logros notables. Mucho de lo sorprendente, elíptico y a veces inconcluso extraño en la escritura de Kawabata puede rastrearse en sus días como integrante de la

Nueva Percepción. (Gessel, 1993, p. 155).

Se despliega, sin embargo, en La pandilla de Asakusa, una situación particular respecto de la estructura de la obra. Por su forma, se trata de una novela atípica en Kawabata. Primer y último intento del novelista japonés por configurar un experimentalismo occidental, que luego regresaría, en efecto, a formas clásicas de escritura, profundamente vinculado, en efecto, a la recuperación de tradiciones nativas:

Con La pandilla investiga, por ensayo y error, buscando qué camino le convendría seguir (...) es el escenario en que tuvo lugar un juego de experimentaciones de "lo ajeno" como manera de amigarse con "lo propio". Una novela rompedora y catártica, incluso al señalar caminos que después el propio Kawabata no recorrería. (Silva, 2007, p. 7).

Es decir, en el ejercicio de enunciación de la novela operan los mismos signos de la reconversión social que Kawabata asimila en Asakusa: el encuentro de la tradición japonesa con la novela occidental moderna. En novelas posteriores, Kawabata no abandona nunca el motivo de la influencia occidental en Japón, pero nunca el tratamiento de dicha problemática utiliza las formas que despliega en La pandilla de Asakusa. A pesar de esto resulta evidente que Kawabata intuye que las reconversiones sociales que tienen lugar en Asakusa deben ser tratadas desde una lógica fragmentaria. En efecto, como supone Lippit, en la novela se impone ciertamente una multiplicidad de estilos de escritura y géneros, junto con palabras en otros idiomas y en argot (Lippit, 1980, como se citó en Silva, 2007). La narración a veces construye imágenes que se revelan fugazmente, como si se tratara de imágenes que ilustran un reportaje. En efecto, el propio Kawabata señaló que su intención era que se tratara de una sucesión de imágenes que diera la impresión de enfrentarse a un noticiario. No existe una única historia, sino que éstas se entrecruzan, quedan pendientes. Los argumentos cambian. Resulta evidente que es una sucesión de perspectivas o lecturas posibles. Algunos personajes desaparecen y reaparecen en momentos inesperados. Las historias se interrumpen y abandonan para ser retomadas en páginas siguientes o al final de la 
novela. Se rompe, en resumidas cuentas con la idea de continuidad. El fragmento es lo que se impone, y la organicidad del texto está dada precisamente por la mirada flâneur, que es la mirada del narrador, pero también es la mirada de los miembros de la pandilla escarlata, pues ellos también, sin ser observados y encapuchados, siguen a sujetos que destacan, por alguna característica, en medio de la multitud. Sucede que "la mirada urbana no es meditativa, sino una rápida visión del sinnúmero de espectáculos que pasan frente a los ojos del espectador como un paisaje visto a través de la ventanilla de un tren" (Freedman, 2002, p. 172). Kawabata es consciente de esta situación y lo ofrece es precisamente es una mirada que recoge sobre Asakusa los fragmentos y que se organiza precisamente en el acto de mirar. La experiencia moderna no resiste otro tratamiento,

De ahí que, como historia, no apunta a una delineación integrada y consistente de personajes y acontecimientos; estos últimos son tratados simplemente como burbujas de todas clases y formas, que originan las corrientes agitadas de Asakusa, aparecen y se desvanecen a su antojo, creando así, numerosos puntos focales en el relato y dando la sensación simultánea de cosa complicada y multifacético (...) Cortando, conectando, superponiendo, desovillando, la historia se dibuja confusamente, variable e intrincada, de una manera muy parecida al cine. (Kataoka, 1939, p. 339).

Todos los fragmentos tienen ante el flâneur el valor de signo. Su significado es difuso, disperso, pero luego son transformados en rasgos de una identidad construida, especulada, fragmentaria. Al mismo tiempo que su fugaz ánimo experimental, Kawabata intuye que ese es el tratamiento que una experiencia de tal tipo requiere. Su novela, en efecto, fue publicada a partir de 1930 por entregas en un periódico de vasta popularidad en Tokio. Evidentemente ostenta rasgos vanguardistas y no es casualidad que haya sido retomada posteriormente en forma de cómic, ya que, en efecto el tratamiento de la imagen y sus personajes se prestan para ello. Leer La Pandilla de Asakusa es, por su lógica fragmentaria, como enfrentarse ciertamente a las viñetas y a la lógica de corte e interrupción, pero también de continuidad, de una revista de cómic. De alguna manera los personajes de Kawabata en Asakusa inauguraron el síndrome que progresivamente produjo lo que hoy se conoce como la cultura pop de Japón. Por lo demás, ciertamente la estética desplegada por Kawabata en la novela remite a los personajes que aparecen por doquier en los mangas y animés japoneses de finales de siglo XX y XXI.

La fricción de Kawabata entre la tradición del naturalismo literario japonés y la experimentación de la novela moderna occidental, aparece expuesta de modo explícito en la utilización que se hace del narrador. La mezcla de estilos que supone La pandilla de Asakusa, se manifiesta también, desde luego, en ese ámbito. De pronto es simplemente un narrador personaje, arrastrado por la lógica de la fragmentariedad y de las lecturas o descripciones. En otras ocasiones, y repentinamente, alcanza no obstante, un estatus diferente. Se trata, curiosamente, de un narrador de orden autorial, o que pretende serlo. Por momentos, ciertamente, no es arrastrado por la fragmentariedad del relato, sino que él mismo la impone y determina "Escribí el resto del relato hace siete años. Salteemos un poco... (...) Volvamos al comienzo (2007, p. 189)", pero existen otras ocasiones en las que el narrador interpela a los lectores, llamándolos precisamente, como a la usanza de los narradores decimonónicos, Querido lector. Esta situación es relevante debido al hecho mismo de que Kawabata se ha propuesto sintetizar las formas experimentales de la novela occidental con las tradiciones japonesas. Dice el narrador, arrogándose derechos de omnipotencia:

Quiero hablar del modo en qué lo hacían en la antigua Edo. Tomemos este camino. Sí, debemos determinar, mi querido lector, si este camino a través del cual te voy a conducir a los lugares frecuentados por la pandilla escarlata es el mismo camino en el que, según se dijo, en los viejos días de los emperadores Manji y Kanbum, hombres vestidos de blanco (...) viajaban de un lado al otro del Yoshiwara. (Kawabata, 2007, p. 47-48).

Quiero hablar del modo en qué lo hacían en los días de la antigua Edo, dice el narrador. Sin embargo resulta evidente que ya no puede hablarse, o narrarse, como se hacía entonces. No, al menos, cuando se narran las transformaciones que están teniendo lugar en Asakusa. El narrador autorial, que interpelaba al lector, tenía sentido en un momento en que existía una comunidad y se 
poseían saberes y metarrelatos dignos de crédito. Podía erigirse una voz con autoridad e interpelar al lector (Martínez Bonati, 1995), pues se trataba de un momento en que las sociedades eran aún comunidades y no artefactos. La única posibilidad que le cabe al narrador autorial es una aparición irónica, desde la parodia. No alcanza ese, sin embargo, a ser, aparentemente, la idea de Kawabata y, por ello, el narrador autorial se difumina a sí mismo, aparece esporádicamente y sucumbe ante la lógica fragmentaria. Parece ser que el narrador autorial que introduce Kawabata se vincula precisamente con la dicotomía que percibe entre la tradición milenaria y la emergencia de la ciudad moderna, de algún modo como si se asistiera al fin de la sabiduría y de la experiencia, donde el narrador decimonónico expresa el extrañamiento de esa sabiduría en el nuevo orden, y, desde luego, la nostalgia por dicho extrañamiento.
Al finalizar, cabe señalar que en La pandilla de Asakusa confluyen los elementos que permiten su lectura desde la lógica del flâneur: un sujeto deambula por un espacio de "corte" occidental y moderno y en un momento en que se produce la desintegración de la idea de comunidad y de sujeto, rastrea signos dispersos, apenas fragmentos, con los cuales constituir una identidad especulada: la instalación, en definitiva, de una estética moderna. Después de su novela ambientada en Asakusa, Kawabata no regresó más a una estructura del orden ahí desplegado. Asakusa dejó luego también de ser lo que fue alguna vez, sobre todo luego de la Segunda Guerra Mundial, cuando fue bombardeado, severamente dañado y sustituido por otros barrios y emplazamientos como espacio de diversión y placer. Ya no era, tampoco, necesario que existiera. Lo que Asakusa había sido a nivel marginal, como un crisol o laboratorio, se había extendido ya más allá de sus límites. 


\section{Referencias}

Anderson, B. (1991). Comunidades imaginadas. Reflexiones sobre el origen y la difusión del nacionalismo. México, DF: Fondo de Cultura Económica.

Baudelaire, C. (1961). Obras Completas. Madrid: Aguilar.

Baudelaire, C. (1997). Pequeños Poemas en Prosa. Madrid: M. E. Editores.

Beck, U., Giddens, A., \& Lash, S. (2001). Modernización reflexiva. Política, tradición y estética en el orden social moderno. Madrid: Alianza.

Benjamin, W. (1991). El país del Segundo Imperio en Baudelaire. En W. Benjamin (Autor), Poesía y Capitalismo (pp. 49-83). Madrid: Taurus.

Benjamin, W. (2018). Experiencia y pobreza. En W. Benjamin (Autor), Iluminaciones (pp. 110-122). Madrid: Taurus Clásicos Radicales.

Bürger, P. (2010). Teoría de la Vanguardia. Buenos Aires: Las cuarenta.

Calatrava, J. (2016). El París de Haussmann como territorio de la utopía: Victor Fournel (1865) y Victor Hugo (1867). Revista Quintana, 15, 53-71.

Campaña, M. (2017). Baudelaire. Juego sin triunfos. Barcelona: Debolsillo.

Castro, R. (2009). La ciudad apestada. Neoliberalismo y postpanóptico. Revista de Ciencia Política, 29(1), 165-183.

Debord, G. (1999). La sociedad del espectáculo. Valencia: Pre-textos.

Escobar, A. (2018). Las barricadas de París, de Haussmann a Mayo del 68: una aproximación poética y sociológica. Guerra y Violencia en la Literatura y en la Historia. Seminario Interdisciplinar de Historia y Literatura, 5, 171-179.

Foucault, M. (2006). Vigilar y Castigar. Nacimiento de la prisión. Buenos Aires: Siglo XXI Editores.

Foucault, M. (2007). El poder psiquiátrico. Curso en el Collège de France (1973-1974). Buenos Aires: Fondo de Cultura Económica.

Freedman, A. (2002). Tracking Japanese Modernity: Commuter Trains, Streetcars, and Passengers in Tokio Literatura, $1905-$ 1935. [Tesis Doctoral]. Universidad de Chicago.
Gessel, Van C. (1993). Three Modern Novelists: Soseki, Tanizaki, Kawabata. Tokio: Kodansha Internacional.

Habermas, J. (2004). Modernidad: un proyecto incompleto. En N. Casullo (Ed.), El debate modernidad-posmodernidad (pp. 53-63). Buenos Aires: Retórica.

Harvey, D. (2006). París, capital de la Modernidad. Madrid: Akal. Jameson, F. (2012). Posmodernismo. La lógica cultural del capitalismo avanzado (Vol. I). Buenos Aires: La Marca Editora.

Kataoka, Y. (1939). Introduction to Contemporary Japanese Literature. Tokio: Kokusai Bunka Shinkokai.

Kawabata, Y. (2007). La pandilla de Asakusa. Buenos Aires: Emecé lingua franca.

Keene, D. (1984). Dawn to the West: Japanese Literature of the Modern Era (Vol. 3). Nueva York: Holt, Rinehart, and Winston.

López-Castellón, E. (1997). Lectura ética de Pequeños poemas en prosa. En C. Baudelaire (Autor), Pequeños poemas en prosa (pp. 19-92). Madrid: M.E. Editores.

Martínez Bonati, F. (1995). El sentido de algunas transformaciones del arte narrativo. Revista Chilena de Literatura, 47, 5-26.

Morales, L. (2002). El lugar del flâneur en la antipoesía. Revista Atenea, 485, 31-41.

Morales, L. (2004). Diamela Eltit: El ensayo como estrategia narrativa. Revista Atenea, 490, 131-144.

Muñoz Millanes, J. (1998). Fenomenología del flâneur. Modos y Afectos del fragmento. Valencia: Pre-textos.

Raymond, M. (1961). De Baudelaire al surrealismo. México, DF: Fondo de Cultura Económica.

Richie, D. (2007). Prefacio a La pandilla de Asakusa. En Y. Kawabata (Autor), La pandilla de Asakusa (pp. 21-44). Buenos Aires: Emecé lingua franca.

Silva, A. (2007). Presentación a La pandilla de Asakusa. En Y. Kawabata (Autor), La pandilla de Asakusa (pp. 9-21). Buenos Aires: Emecé lingua franca.

Tanisaki, J. (1993). The secret. In A. Gatten \& A. Hood Chambers (Eds.), New leaves: Studies and Translation of Japarnese Literature in Honor of Edgar Seidensticker. Center for Japanese Studies: University of Michigan. 


\section{Notas al final}

1 Más exacto es señalar que solo los primeros 37 capítulos de la novela se publicaron en Asahi Shimbun entre diciembre de 1929 y marzo de 1930. Los 24 capítulos restantes aparecieron entre septiembre y diciembre de 1930, pero ya no en el popular vespertino sino en las revistas de izquierda no marxista Kaizo y Shinchó.

2 La pandilla de Asakusa, a pesar de ser uno de los primeros textos de Kawabata, fue el último en traducirse a lenguas occidentales: al inglés el 2005 y al español el 2007, en la edición que aquí citamos.

3 La revolución de 1848 fue una revuelta popular que obligó al rey Luis Felipe I a abdicar, dando pasos a la Segunda República Francesa. Charles Baudelaire participó activamente de esta insurrección.

4 El 2 de diciembre de 1851, Luis Napoleón Bonaparte, Napoleón III, dio un golpe de Estado. Un año después se proclamaría un imperio que habría de extenderse hasta 1872. Es importante mencionar que el Golpe de de Estado de 1851 afectó profundamente a Baudelaire debido a la tenue resistencia que encontró Napoleón III para ejecutar sus planes, especialmente fuera de París. 